\title{
p21: a monitor of p53 dysfunction in ovarian neoplasia
}

\author{
K. SHIGEMASA*, C. HU§, C. M. WEST*, S. H. MOON $\dagger$, G. P. PARHAM*, T. H. PARMLEY*, S. \\ KOROURIAN $\$$, V. V. BAKER§ \& T. J. O'BRIEN*† \\ Departments of Obstetrics and Gynecology*, Biochemistry and Molecular Biology†, Pathology:, University of Arkansas for \\ Medical Sciences, Little Rock, Arkansas, USA; Division of Gynecology Oncology§, University of Michigan Medical Center, \\ Ann Arbor, Michigan, USA
}

\begin{abstract}
Shigemasa K, Hu C, West CM, Moon SH, Parham GP, Parmley $\mathrm{TH}$, Korourian S, Baker VV, O'Brien TJ. p21: a monitor of p53 dysfunction in ovarian neoplasia. Int J Gynecol Cancer 1997; 7: 296-303.

p53 is an important tumor suppressor gene which is activated in response to DNA damage. The induced expression of p53 causes either cell cycle G1 arrest or apoptosis. The recently cloned p21 gene (WAF1/ CIP1/SDI1) is known to be directly activated by wild-type but not mutant p53 and can suppress the growth of human cells in G1 by inhibiting the activity of cyclin-dependent kinases (CDKs). As p21 is activated by p53 and is a negative regulator of the cell cycle, it is possible that p21 could be a sensitive marker to monitor $\mathrm{p} 53$ function. To investigate the mRNA expression level and mutation status of p53 and p21 genes, quantitative polymerase chain reaction (PCR) and direct cDNA sequence analysis were performed. mRNA expression levels of p53 and p21 genes relative to the $\beta$-tubulin gene were examined in 32 ovarian tumors (24 carcinomas, six low malignant potentials (LMPs), two benigns) and six normal ovaries. Of 13 ovarian tumors with p21 underexpression, nine p53 mutated cases $(69 \%)$ and one polymorphism case were found. Among nine p53 mutated cases, three cases showed p 53 overexpression, another three cases showed p53 underexpression and a further three cases showed normal expression of p53. These findings suggest that mRNA underexpression of p21 may be a more useful indicator of p53 dysfunction than mRNA expression of p53.
\end{abstract}

KEYWORDS: mRNA expression, mutation status, ovarian cancer, p21, p53.

Ovarian cancer is the fourth most common cause of female cancer death and the most common cause of death from gynecologic cancer ${ }^{(1)}$. As ovarian cancer is often asymptomatic in its early stages, a majority of the patients are diagnosed at an advanced clinical stage despite recent advances in imaging technology and the availability of assay systems for serum tumor markers $^{(2)}$. It therefore remains necessary to develop new diagnostic markers for screening women at risk for ovarian cancer.

Even though the genetic alterations involved in ovarian carcinoma remain largely unknown, as is the

Address for correspondence: Dr T. J. O'Brien, Biomedical Biotechnology Center, University of Arkansas for Medical Sciences, 4301 West Markham Street, Slot 718, Little Rock, AR 72205, USA. case with other common human carcinomas, a series of multiple genetic defects are believed to be involved in the development of ovarian cancer ${ }^{(3)}$. Some genetic abnormalities can alter the normal function of cancerrelated gene products quantitatively and/or qualitatively, thereby it is necessary to evaluate over/underexpression as well as mutation in the carcinogenic process $^{(4)}$.

Currently established prognostic factors for ovarian cancer, including clinical stage, histologic type and histological grade, provide a framework for the selection of appropriate treatment. However, there remains the need to catalog the genetic insults relative to both prognosis and treatment response so that therapy can be individualized and directed toward control of the biologic aberrations. 
p53 is activated in response to DNA damage and the induced expression of p53 causes either cell cycle G1 arrest or apoptosis ${ }^{(5-7)}$. This blockade of DNA synthesis prevents the accumulation of mutations that could contribute to the development of neoplastic cells. p21 (WAF1/CIP1/SDI1), which encodes an inhibitor of cyclin-dependent protein kinase, could explain at least some of the mechanism by which elevated levels of the normal p53 can block cell growth and differentation. p21 (WAF1/CIP1/SDI1) ${ }^{(8-11)}$ is directly activated by wild-type but not human mutant-type p53 and can suppress the growth of human cells by inhibiting the activity of cyclin-dependent kinases (CDKs), which are required for the $\mathrm{G} 1$ to $\mathrm{S}$ transition of the cell cycle. As p21 is a negative regulator of the cell cycle, it is possible that p21 itself can act as a tumor suppressor gene. It has been reported that mutations within the coding portion of the p21 gene were undetectable in a large series of human tumors and that p21 alterations in expression might be caused through p53 mutation rather than through intragenic mutations of the p21 gene itself ${ }^{(12)}$. These findings suggest that p21 could be a sensitive marker to monitor p53 dysfunction. In the present study, we attempted to determine the relationship between mRNA expression of the p53 and p21 genes and the mutational status of the p53 gene in ovarian tumors. The expression level of each gene was determined by using a quantitative polymerase chain reaction (PCR) technique and mutation analysis was performed by direct cDNA sequencing.

\section{Patients and methods}

\section{Tissue samples}

Fresh surgical specimens of ovarian epithelial tumors were obtained from 32 patients. They consisted of two benign cystadenomas, six cystadenomas of low malignant potential (LMP) and 24 cystadenocarcinomas. Clinical staging was determined according to the criteria of FIGO. Normal ovaries were obtained from six patients who underwent surgery for benign gynecological disease. The materials were collected immediately after the surgical procedure were frozen in liquid nitrogen and stored at $-80^{\circ} \mathrm{C}$.

\section{mRNA isolation}

mRNA was prepared by using a RioSep mRNA Isolation Kit (Becton Dickinson Labware). 0.5-1.0 g of tissue samples were ground in a mortar and pestle under liquid nitrogen. Ten $\mathrm{ml}$ of lysis buffer and $2 \mathrm{mg}$ of proteinase- $K$ were added and the slurry was homogenized for $30 \mathrm{~s}$. The tissue lysate was incubated for $2 \mathrm{~h}$ at $45^{\circ} \mathrm{C} .600 \mu \mathrm{l}$ of $5 \mathrm{M} \mathrm{NaCl}$ was added to adjust the $\mathrm{NaCl}$ concentration. Ten $\mathrm{ml}$ of tissue lysate was added to an oligo (dT) cellulose tube containing $1 \mathrm{ml}$ of binding buffer and this tube was incubated for $1 \mathrm{~h}$. Oligo (dT) cellulose was pelleted by centrifugation and washed with $5 \mathrm{ml}$ of binding buffer several times. Washed oligo (dT) cellulose was transferred to a column and mRNA was eluted with elution buffer. The amount of mRNA recovered was measured by UV spectrophotometry.

\section{cDNA synthesis}

Complementary DNA was synthesized using a first strand cDNA synthesis kit (CLONTECH). The cDNA synthesis reaction was performed with $5.0 \mu \mathrm{mol}$ of dNTPs, $5 \mu \mathrm{g}$ of mRNA and 20 pmole of random hexmer primer in $20 \mu \mathrm{l}$ of a solution containing $50 \mathrm{mM}$ tris- $\mathrm{HCl}$ (pH 8.3), $75 \mathrm{mM} \mathrm{HCl}, 3 \mathrm{mM} \mathrm{MgCl} 2,500 \mu \mathrm{M}$ each dNTP, one unit of RNase inhibitor and 200 units of Moloney-Murine Leukemia Virus reverse transcriptase. After $4 \mathrm{~h}$ of incubation at $42^{\circ} \mathrm{C}$, the reaction was heated to $94^{\circ} \mathrm{C}$ for $5 \mathrm{~min}$ to stop cDNA synthesis and cDNA was diluted to a final volume of $100 \mu \mathrm{l}$. The efficiency of the cDNA synthesis was estimated by using G3PDH (glyceraldehyde-3 phosphate dehydrogenase) as a positive control amplimer (CLONTECH).

\section{Quantitative PCR}

Quantitative PCR was performed according to the method of Noonan et al. ${ }^{(13)}$ with some modification. Polymerase chain reaction was carried out in a Thermal Cycler (Perkin-Elmer Cetus) with the mixture consisting of cDNA derived from $50 \mathrm{ng}$ of mRNA, 5 pmol of sense and antisense primers for both the target gene and the $\beta$-tubulin gene, $200 \mu \mathrm{mol}$ of dNTPs, $5 \mu \mathrm{Ci}$ of $\left[\alpha-{ }^{32} \mathrm{P}\right] \mathrm{dCTP}$ and 0.25 units of Taq DNA polymerase with reaction buffer (Promega) in a final volume of 25 $\mu 1$. The primer sequences used for quantitative PCR are listed in Table 1. Pairs of the primers were designed to include intron sequences as a monitor of genomic

Table 1. Sequences of amplification primers used for quantitative PCR

\begin{tabular}{llll}
\hline Gene & & \multicolumn{2}{c}{ Primer } \\
\hline p53 & 4A & sense & 5-AGGCGCTGCCCCACCA-3 \\
& 4B & antisense & 5-TTCCGTCCCAGTAGATT-3 \\
p21 & 1A & sense & 5-GCCGAAGTCAGTTCCTT-3 \\
& 2B & antisense & 5-TCATGCTGGTCTGCCGC-3 \\
$\beta$-tubulin & & sense & 5-TGCATTGACAACGAGGC-3 \\
& & antisense & 5-CTGTCTTGACATTGTTG-3 \\
\hline
\end{tabular}


DNA contamination in the PCR mix. The primer sequences used in this study were designed according to the cDNA sequences described by Lamb et al. $(\mathrm{p} 53)^{(14)}$, El-Deiry et al. $(\mathrm{p} 21)^{(9)}$ and Hall et al. ( $\beta$ tubulin $)^{(15)}$. The target sequences were amplified in parallel with the $\beta$-tubulin gene as an internal control. Each cycle of PCR included $30 \mathrm{~s}$ of denaturation at $95^{\circ} \mathrm{C}, 1 \mathrm{~min}$ of primer annealing at $62^{\circ} \mathrm{C}$ and $1 \mathrm{~min}$ of extension at $72^{\circ} \mathrm{C}$. Thirty cycles of PCR were performed. The products were separated on $2 \%$ agarose gel and the radioactivity of each band was determined by a Phospho-Imager (Molecular Dynamics). The statistical significance of the correlation between p21 underexpression and p53 mutation was examined using the $\chi^{2}$ test.

\section{Direct cDNA sequencing}

Polymerase chain reaction was carried out with the amplification primers described in Table 2. p53 cDNA was sequenced from codon 7 to codon 351 extending from the middle of exon 2 to the middle of exon 10 . Amplified cDNA samples were purified using the Wizard PCR DNA Purification System (Promega). The sequencing reaction was carried out using Prism ReadyReaction Dyre Deoxy Terminators, the completed sequencing reaction was purified using a Centri-Sep Spin Column (Princeton Separations). The Applied Biosystems Model 373A DNA Sequencing System was used for direct $\mathrm{cDNA}$ sequence determination.

\section{Immunohistochemistry}

Immunohistochemical staining was performed using a VECTASTAIN Elite ABC kit (Vector). Formalin fixed and paraffin embedded specimens were routinely deparaffinized and processed using microwave heat treatment in $0.01 \mathrm{M}$ sodium citrate buffer ( $\mathrm{pH} \mathrm{6)}$. The specimens were incubated in methanol with $0.3 \%$ $\mathrm{H}_{2} \mathrm{O}_{2}$ for $30 \mathrm{~min}$ at room temperature, the samples

Table 2. Sequences of amplification primers used for direct sequencing

\begin{tabular}{llll}
\hline Gene & \multicolumn{3}{c}{ Primer } \\
\hline p53* & 2A & sense & 5-ATCCTAGCGTCGAGCCC-3 \\
& 2B & antisense & 5-TTTCTGGGAAGGGACAG-3 \\
3A & sense & 5-CTGGCCCCTGTCATCTT-3 \\
3B & antisense & 5-TATCTGAGCAGCGCTCA-3 \\
4A & sense & 5-AGGCGCTGCCCCACCA-3 \\
4B & antisense & 5-TTCCGTCCCAGTAGAT-3 \\
5A & sense & 5-TGGAAGACTCCAGTGGT-3 \\
5B & antisense & 5-CTTGAGTTCCAAGGCCT-3 \\
\hline
\end{tabular}

*p53 sequence covers from aa 7 to aa 351 (sequences goes from the middle of exon 2 to the middle of exon 10). were incubated with anti-p53 protein monoclonal antibody (IMMUNOTECH) for $1 \mathrm{~h}$ at room temperature in a moisture chamber, followed by incubation with biotinylated anti-mouse IgG (Vector) for $30 \mathrm{~min}$ at room temperature, and then incubated with $A B C$ reagent (Vector) for $30 \mathrm{~min}$ at room temperature. The final products were visualized by using the AEC Substrate System (DAKO) and sections were counterstained with hematoxylin before mounting. Negative controls were performed by using normal serum instead of the primary antibody.

\section{Results}

\section{Quantitative PCR}

Since differences in the extent of RNA degradation and purity between different preparations can have a great effect on the yield of PCR products, the target sequence was amplified in parallel with an internal control sequence corresponding to a common mRNA expressed in the same cell. Ideally, the control sequence should be present at similar levels in different types of cells (normal and tumor) and at an abundance comparable to that of target sequence.

In our initial study for quantitative PCR, we tested the $\beta$-actin gene, the $\beta$-tubulin gene and the G3PDH (glyceraldehyde-3 phosphate dehydrogenase) gene as potential internal controls for both p53 and p21 quantitative PCR analysis. The expression levels of $\beta$ actin gene and G3PDH gene were so dominant compared to those of p53 and p21 genes that both $\beta$ actin gene and G3PDH gene were deemed as unsuitable for use as an internal control gene in the quantitative PCR (data analysis not shown). We found that the $\beta$-tubulin gene expression, however, showed reasonably similar expression levels to that of the p53 and the p21 genes and the expression level of $\beta$ tubulin was consistent in both normal cells and cancer cells. Accordingly, we decided to use the $\beta$-tubulin gene as an internal control gene in this study.

In order to determine the number of PCR cycles appropriate for quantitation, PCR was performed from 15 to 35 cycles over five cycle intervals and linearity of the $\beta$-tubulin PCR products was monitored using ${ }^{32} \mathrm{P}$ labelling agarose gels and phosphoimager quantitation of the labelled PCR products. The amplification reaction was measured as the $\log$ of ${ }^{32} \mathrm{P}$ incorporation and was found to be linear over 30 cycles (Fig. 1). The PCR reaction was also found to be linear when both p53 and $\beta$-tubulin primers of p21 and $\beta$-tubulin primers were co-amplified (data not shown). All ensuing PCR reactions were therefore carried out for 


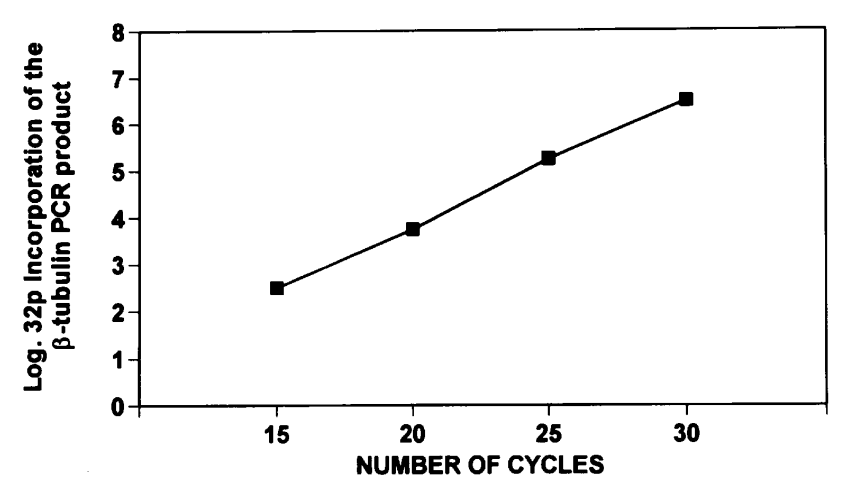

Fig. 1. The linearity of the $\beta$-tubulin PCR product was constant over 30 cycles.

30 cycles. The primers used for both quantitative PCR analysis of p21 and p53 and direct cDNA sequencing of p53 are shown in Table 1 and Table 2, respectively.

\section{p53 expression}

Expression levels of p53 mRNA as measured by quantitative PCR were evaluated in six normal, two benign and six LMP tumors and 24 ovarian carcinomas (Fig. 2). The expression levels of p53 relative to $\beta$ tubulin were higher in seven ovarian cancer cases $(29 \%)$ and lower in four cancer cases (17\%) than that in normal ovaries. p53 levels were also lower in two LMP tumors (33\%). Abnormal expression of p53 (either higher or lower) was found in seven out of $17(41 \%)$ serous cystadenocarcinomas and three out of four (75\%) mucinous cystadenocarcinomas. These observations are demonstrated in Fig. 3 where underexpression of p53 compared to normal is noted in cases 31 and 36 and overexpression of p53 is noted in Case 33. An aberrant p53 amplification product is also noted in Case 33 (Fig. 3).

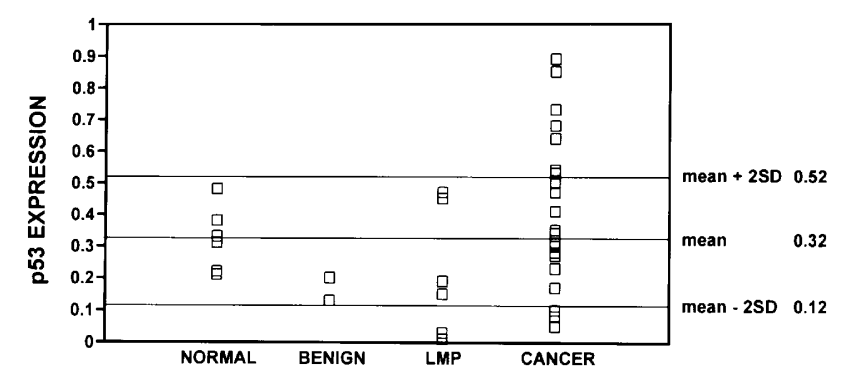

Fig. 2. p53 expression relative to $\beta$-tubulin in normal ovary, benign ovarian tumor, LMP tumor and ovarian cancer. Expression levels of p53 were higher in some cancer cases compared to normal ovaries. Some ovarian tumor cases showed lower p53 expression than normal ovaries.

(C) 1997 IGCS, International Journal of Gynecological Cancer 7, 296-303

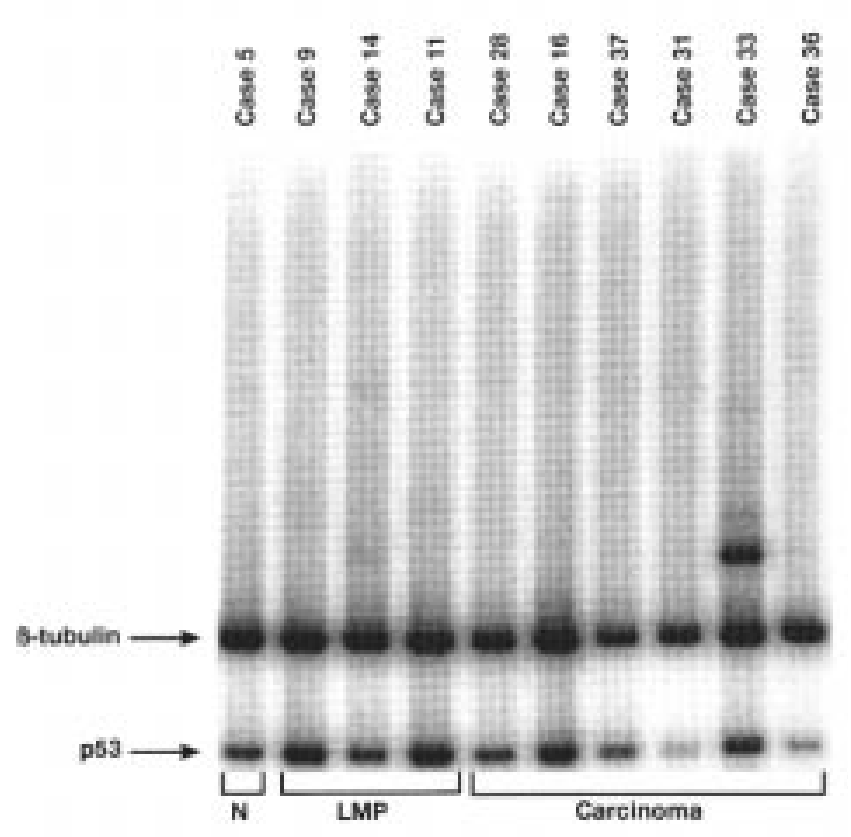

Fig. 3. p53 and $\beta$-tubulin PCR products. Case 5 is a normal ovary. Cases 9, 14 and 11 are LMP tumors. Cases 28, 16, 37, 31, 33 and 36 are ovarian cancers. Case 33 showed one extra p53 product. Expression levels of p53 are higher in Case 33 and lower in Case 31 and Case 36 than that of normal ovaries.

\section{p21 expression}

p21 expression levels were lower in three LMP tumors (50\%) and in 10 ovarian cancer cases (42\%) than that of normal ovaries (Fig. 4). p21 underexpression was found in two out of four stage I-II cases and in eight out of 20 stage III-IV cases (Table 3). Underexpression of p21 was also found in seven out of 17 serous cystadenocarcinomas and two out of four (50\%) mucinous cystadenocarcinomas. Expression of p21 relative to $\beta$-tubulin is shown in Fig. 5 comparing normal tissue (Cases 1, 3, 4) to an LMP tumor, (Case 12) and to three carcinomas (Cases 22, 29, 36). All tumors underexpress p21. In contrast, one serous cystadenocarcinoma case showed higher p21 expres-

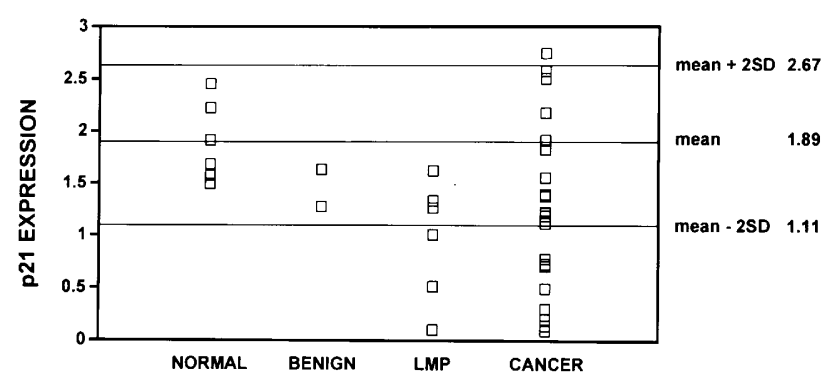

Fig. 4. p21 expression relative to $\beta$-tubulin in normal ovary, benign ovarian tumor, LMP tumor and ovarian cancer. p21 expression levels of ovarian tumor were often lower than that of normal ovaries. 
Table 3. Number of cases with overexpression or underexpression of p53 and p21

\begin{tabular}{lrllc}
\hline & & $\begin{array}{l}+ \text { p53 } \\
+2 \text { SD or } \\
\text { greater }\end{array}$ & $\begin{array}{l}- \text { p53 } \\
\text { or less }\end{array}$ & $\begin{array}{l}\text { p21 } \\
\text { or less }\end{array}$ \\
\hline Normal ovary & 6 & $0(0 \%)$ & $0(0 \%)$ & $0(0 \%)$ \\
Benign tumor & 2 & $0(0 \%)$ & $0(0 \%)$ & $0(0 \%)$ \\
LMP & 6 & $0(0 \%)$ & $2(33 \%)$ & $3(50 \%)$ \\
Carcinoma & 24 & $7(29 \%)$ & $4(17 \%)$ & $10(42 \%)$ \\
$\quad$ stage I/II & 4 & $2(50 \%)$ & $1(25 \%)$ & $2(50 \%)$ \\
$\quad$ stage III/IV & 20 & $5(25 \%)$ & $3(15 \%)$ & $8(40 \%)$ \\
Type & & & & \\
$\quad$ serous & 17 & $5(29 \%)$ & $2(12 \%)$ & $7(41 \%)$ \\
$\quad$ mucinous & 4 & $2(50 \%)$ & $1(25 \%)$ & $2(50 \%)$ \\
$\quad$ endometrioid & 1 & $0(0 \%)$ & $1(100 \%)$ & $1(100 \%)$ \\
$\quad$ clear cell & 2 & $0(0 \%)$ & $0(0 \%)$ & $0(0 \%)$ \\
\hline
\end{tabular}

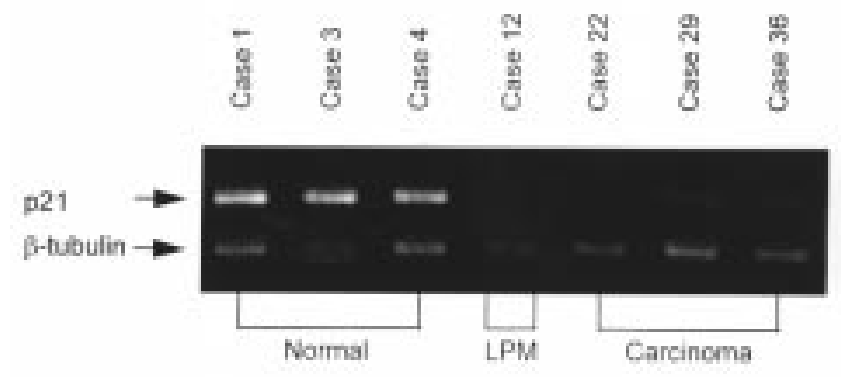

Fig. 5. p21 and $\beta$-tubulin PCR products. Cases 1,3 and 4 are normal ovaries. Case 12 is an LMP tumor. Cases 22, 29 and 36 are ovarian cancers. p21 expression relative to $\beta$-tubulin is lower in these tumor samples than that in normal ovaries.

sion (data not shown). Out of 13 ovarian tumor cases with p21 underexpression, eight cases have aberrant p53 expression (either higher or lower than normal).

Abnormal expression of p53 and underexpression of p21 are compared in Table 3. As noted no abnormal changes were observed in the two benign specimens. In the LMP group p53 underexpression was observed in two of six specimens and p21 underexpression was noted in three of six tumors. For carcinomas, 11 of 24 (46\%) showed abnormal p53 expression while 10 of 24 (42\%) were shown to underexpress the p21 tumor suppressor gene. For serous cystadenocarcinomas, seven of 17 tumors (41\%) demonstrated abnormal p53 expression and seven $(41 \%)$ were also found to underexpress p21 (Table 3).

\section{p53 mutations}

All tumors which demonstrated abnormal expression of p53 or underexpression of p21 (a total of 18 cases) were examined for $\mathrm{p} 53$ mutations by direct sequencing of the PCR products. Six of the 13 (six of 13) tumors which showed abnormal p53 expression were found to be mutated. For the six mutated cases, three showed underexpression of p53 and three showed overexpression of p53 (Table 4).

Out of the 13 ovarian tumor cases with underexpression of p21, nine p53 mutations (69\%) were found (Fig. 6). According to the quantitative PCR data, three out of these nine cases showed overexpression of p53, three cases showed underexpression of p53 and three case showed normal p53 expression. Out of five ovarian cancer cases that showed abnormal expression of p53, but did not show underexpression of p21, no p53 mutation was found.

Two cases showed unusual PCR patterns. Case 33 showed two bands instead of one, an unexpected band of $635 \mathrm{bp}$ and the expected band at $285 \mathrm{bp}$ (Figs 3 \& 6). The larger sized product had a $\mathrm{G}$ to $\mathrm{T}$ transversion at the $3^{\prime}$ splicing site of intron-7 that resulted in intron 7 insertion (Table 5). The anticipated PCR product of 285 bp was also altered and shown to contain a $\mathrm{T}$ to $\mathrm{A}$ transversion in codon 206 converting it from a leucine codon to a stop codon. In Case 26 an extra p53 product in addition to the expected sized p53 product was detected (Fig. 6). In this case the smaller sized product had a $58 \mathrm{bp}$ deletion from codon 106 to codon 125 which resulted in stop codon at codon 150 . The mutations observed in p53 are spread over exons 4 through 7 and all predict an amino acid change in the regulatory domain of the p53 protein (Table 5). As already mentioned we also observed a deletion of amino acids 106 to 125 in Case 26 and an insertion of intron 7 due to a splice site mutation in Case 33 (Table 5).

\section{p53 immunohistochemistry}

Four normal, one benign and three LMP tumors plus 14 carcinomas were examined for p53 expression by immunostaining. In eight cases with p53 mutation 2+ staining for p53 protein was detected. Increased staining (1+) was also detected in one case with a p53 polymorphism. No increased staining was detected in four normal ovarian or in seven cases with wild-type p53. One LMP case with a p53 polymorphism also showed no increased p53 staining (Table 4).

\section{Discussion}

The mechanism by which elevated levels of normal p53 can block cell growth and differentiation is beginning to be understood. p53 is activated in response to DNA damage ${ }^{(5)}$ and increases transcription of $\mathrm{p} 21^{(9)}$. p21 complexes with and inhibits the activity of cyclin-CDK complex ${ }^{(8,10)}$. Since the cyclinCDK complex stimulates cell division by adding 
Table 4. Expression of p53 and p21 genes and mutation of p53 gene in normal ovaries and ovarian tumors

\begin{tabular}{|c|c|c|c|c|c|c|c|}
\hline \multirow{2}{*}{$\begin{array}{l}\text { Case } \\
\text { no. }\end{array}$} & \multirow{2}{*}{$\begin{array}{l}\text { Histologic } \\
\text { type }^{\mathrm{a}}\end{array}$} & \multirow{2}{*}{$\begin{array}{l}\text { Stage/ } \\
\text { grade }^{b}\end{array}$} & \multirow[b]{2}{*}{ Meta $^{c}$} & \multicolumn{2}{|c|}{ mRNA expression $^{\mathrm{d}}$} & \multirow{2}{*}{$\begin{array}{l}\text { Mutation }^{\mathrm{e}} \\
\text { p53 }\end{array}$} & \multirow{2}{*}{$\begin{array}{l}\text { Immunostaining }^{\mathrm{f}} \\
\text { p53 }\end{array}$} \\
\hline & & & & p53 & $\mathrm{p} 21$ & & \\
\hline 1 & $\mathrm{NO}$ & & & $\mathrm{N}$ & $\mathrm{N}$ & ND & - \\
\hline 2 & NO & & & $\mathrm{N}$ & $\mathrm{N}$ & ND & - \\
\hline 3 & $\mathrm{NO}$ & & & $\mathrm{N}$ & $\mathrm{N}$ & ND & - \\
\hline 4 & $\mathrm{NO}$ & & & $\mathrm{N}$ & $\mathrm{N}$ & ND & - \\
\hline 5 & $\mathrm{NO}$ & & & $\mathrm{N}$ & $\mathrm{N}$ & ND & ND \\
\hline 6 & $\mathrm{NO}$ & & & $\mathrm{N}$ & $\mathrm{N}$ & ND & ND \\
\hline 7 & SA (benign) & & & $\mathrm{N}$ & $\mathrm{N}$ & ND & - \\
\hline 8 & SA (bengin) & & & $\mathrm{N}$ & $\mathrm{N}$ & $\mathrm{Nd}$ & ND \\
\hline 9 & SA (low malignant potential) & $\mathrm{I} / \mathrm{I}$ & NI & $\mathrm{N}$ & $\mathrm{N}$ & ND & - \\
\hline 10 & SA (low malignant potential) & $\mathrm{I} / \mathrm{I}$ & - & $\mathrm{N}$ & $2-$ & WT & ND \\
\hline 11 & MA (low malignant potential) & $\mathrm{I} / \mathrm{I}$ & - & $\mathrm{N}$ & $\mathrm{N}$ & ND & - \\
\hline 12 & MA (low malignant potential) & $\mathrm{I} / \mathrm{I}$ & NI & $2-$ & $2-$ & POL & + \\
\hline 13 & MA (low malignant potential) & $\mathrm{I} / \mathrm{I}$ & NI & $2-$ & $2-$ & MUT & ND \\
\hline 14 & MA (low malignant potential) & $\mathrm{I} / \mathrm{I}$ & $\mathrm{NI}$ & $\mathrm{N}$ & $\mathrm{N}$ & ND & ND \\
\hline 15 & SC & $\mathrm{I} / \mathrm{II}$ & - & $2+$ & $2-$ & MUT & ND \\
\hline 16 & SC & $\mathrm{I} / \mathrm{III}$ & - & $\mathrm{N}$ & $2-$ & MUT & $2+$ \\
\hline 17 & SC & $\mathrm{II} / 1$ & $\mathrm{NI}$ & $2+$ & $\mathrm{N}$ & WT & + \\
\hline 18 & SC & III/II & + & $2+$ & $\mathrm{N}$ & WT & ND \\
\hline 19 & SC & III/III & NI & $\mathrm{N}$ & $\mathrm{N}$ & ND & ND \\
\hline 20 & SC & III/II & NI & $2+$ & $2-$ & WT & ND \\
\hline 21 & SC & III/II & NI & $\mathrm{N}$ & $\mathrm{N}$ & ND & $2+$ \\
\hline 22 & SC & III/III & NI & $\mathrm{N}$ & $2-$ & MUT & $2+$ \\
\hline 23 & SC & III/III & NI & $\mathrm{N}$ & $\mathrm{N}$ & ND & - \\
\hline 24 & SC & III/III & - & $\mathrm{N}$ & $2-$ & MUT & $2+$ \\
\hline 25 & SC & III/III & NI & $\mathrm{N}$ & $\mathrm{N}$ & ND & ND \\
\hline 26 & SC & III/I & NI & $2-$ & $2-$ & MUT & ND \\
\hline 27 & SC & III/II & NI & $\mathrm{N}$ & $\mathrm{N}$ & ND & ND \\
\hline 28 & SC & III/III & NI & $\mathrm{N}$ & $\mathrm{N}$ & ND & - \\
\hline 29 & SC & III/III & NI & $2+$ & $2-$ & MUT & $2+$ \\
\hline 30 & SC & III/III & NI & $\mathrm{N}$ & $\mathrm{N}$ & ND & $2+$ \\
\hline 31 & SC & III/III & + & $2-$ & $2+$ & WT & ND \\
\hline 32 & $\mathrm{MC}$ & I/II & - & $2-$ & $\mathrm{N}$ & WT & - \\
\hline 33 & $\mathrm{MC}$ & III/II & NI & $2+$ & $2-$ & MUT & $2+$ \\
\hline 34 & $\mathrm{MC}$ & III/II & NI & $\mathrm{N}$ & $2-$ & WT & - \\
\hline 35 & $\mathrm{MC}$ & III/I & NI & $2+$ & $\mathrm{N}$ & WT & $2+$ \\
\hline 36 & $\mathrm{EC}$ & III/III & NI & $2-$ & $2-$ & MUT & $2+$ \\
\hline 37 & $\mathrm{CC}$ & III/III & + & $\mathrm{N}$ & $\mathrm{N}$ & ND & - \\
\hline 38 & $\mathrm{CC}$ & III/III & + & $\mathrm{N}$ & $\mathrm{N}$ & ND & ND \\
\hline
\end{tabular}

${ }^{\mathrm{a} N O}$, normal ovary; SA, serous adenoma; MA, mucinous adenoma; SC, serous carcinoma; MC, mucinous carcinoma; EC, endometrioid carcinoma; CC, clear cell carcinoma.

bStage/grade, FIGO stage and histologic grade.

${ }^{\mathrm{c}}$ Meta, lymph node metastasis; NI, not identified.

${ }^{\mathrm{d}} \mathrm{N}$, normal range is equal to Mean $\pm 2 \mathrm{SD} ; 2-$ negative is equal to $-2 \mathrm{SD}$ to $-4 \mathrm{SD} ; 2+$ positive is equal to Mean $+2 \mathrm{SD}$ to $+4 \mathrm{SD}$.

${ }^{\mathrm{e}} \mathrm{ND}$, not done; WT, wild-type; MUT, mutated; POL, polymorphism.

$\mathrm{f}_{2+}>50 \%$ positive tumor cells; $+<50 \%$ positive tumor cells; - , negative.

phosphate to the retinoblastoma $(\mathrm{Rb})$ protein and releasing E2F to activate the transition from G1 to $S$ phase ${ }^{(16)}$, p21 could prevent cells from entering $S$ phase and result in G1 arrest (Fig. 7). As inactivation of the p53 gene by mutation is the most common genetic mutation in human cancers ${ }^{(17)}$, these findings provide a link between dysfunction of p53 and tumor cell progression through the dysregulation of the cell cycle. Since ovarian cancer is one of the tumors in which dysfunction of p53 with mutations occurs fre- quently $^{(18-24)}$, dysregulation of cell cycle control through the p53-p21 pathway could play a critical role in the spread of some ovarian cancers.

It has been reported that $\mathrm{p} 53$ mutations were found in $26-79 \%$ of ovarian cancer tissues, and most of the p53 mutations found in ovarian cancer, similar to other human cancers, were missense mutations in the sequence-specific DNA-binding domain ${ }^{(18-24)}$. In the present study, we found 11 mutations and one polymorphism in nine tumors. Nine of 11 mutations 
were missense mutations and all 11 mutations were found in the cluster of the sequence-specific DNAbinding domain. These data suggest most of the p53 mutations result in the dysregulation of downstream

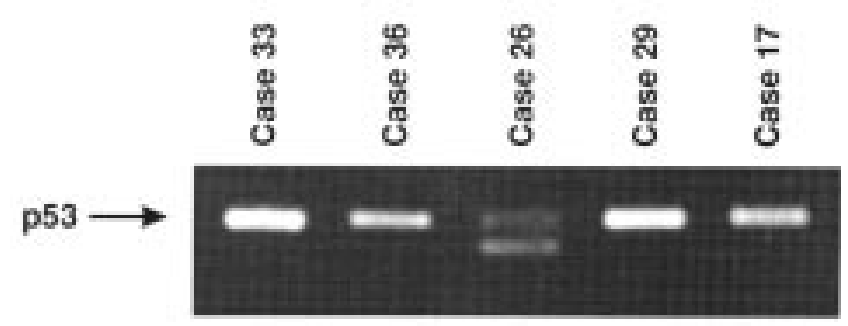

Fig. 6. p53 PCR product prepared for direct sequencing. Case 26 has one extra product.

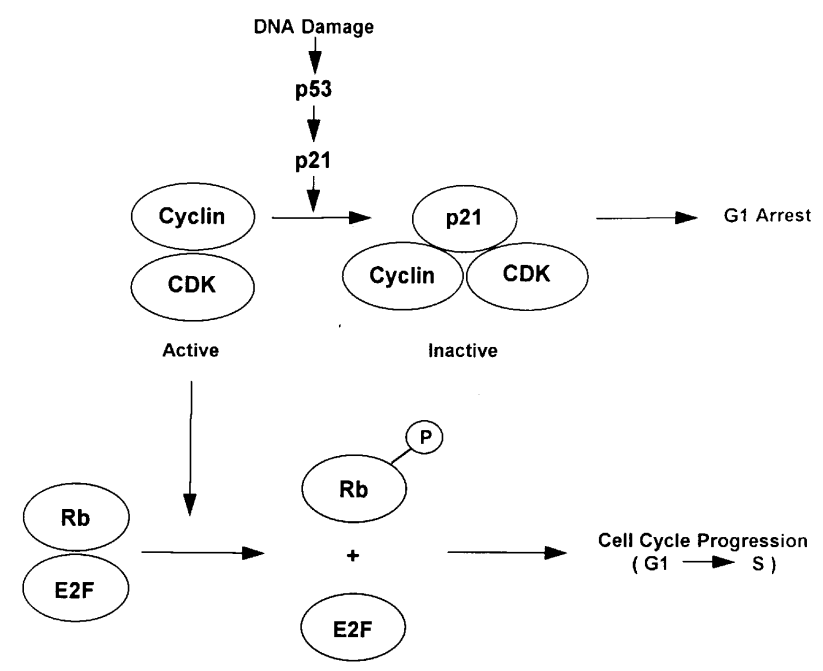

Fig. 7. Cyclin and CDK stimulate cell division by adding phosphate to the retinoblastoma $(\mathrm{Rb})$ protein and releasing E2F that activates the transition from G1 to S phase. p53 is activated in response to DNA damage and increases transcription of p21. p21 complexes with and inhibits the activity of Cyclin-CDK complex and prevents cells from entering $\mathrm{S}$ phase. effectors, such as p21, whose expression is regulated by $\mathrm{p} 53$.

It has not been shown whether the mRNA expression level of p53 is reflected by the p53 mutation status. In the present study of nine p53 mutated cases, three cases showed overexpression of p53, another three cases showed underexpression of p53 and the last three cases showed normal p53 expression. These data suggest that p53 mRNA expression level is not a good indicator of p53 mutation status.

Since p21 is directly activated by wild-type p53 protein but not mutant-type p53 protein $^{(9)}$, downregulation of the p21 mRNA might be expected to occur in the cases with p53 mutation. Our results showed that p21 mRNA expression level was significantly reduced in three LMP tumors and in 10 ovarian cancer cases. Of these 13 ovarian tumor cases with p21 underexpression, nine p53 mutated cases were found $(69 \%)$ and all nine cases resulted in amino acid changes. These findings suggest that mRNA underexpression of $\mathrm{p} 21$ is directly related with $\mathrm{p} 53$ dysfunction regardless of the mRNA expression level of p53.

It has been reported that mutant p53 proteins generally have a much longer half-life than wild-type p53 proteins and the extended half-life of p53 protein leads to its accumulation within the nuclei of affected cells $^{(25-26)}$. Several earlier studies have suggested that immunohistochemical staining of p53 protein is correlated with the presence of p53 missense mutations and it could detect $50-80 \%$ of p53 mutated cases in ovarian tumors ${ }^{(18,22-23)}$ However, some kinds of p53 mutation, such as a nonsense mutation or a splicing alteration and most deletions, do not result in the p53 protein accumulation $^{(18)}$. Furthermore, dysfunction of the p53 protein is not always caused by intra-genic mutations but sometimes caused by several viral and cellular oncoproteins such as the E6 protein ${ }^{(27)}$ of

Table 5. p53 mutations in ovarian tumors with p21 underexpression

\begin{tabular}{lllllll}
\hline Case no. & Tumor type* & FIGO stage & Exon & Codon & Base change & Amino acid change \\
\hline $12^{* *}$ & M adenoma (LMP) & 1 & Exon4 & aa72 & CGC-CCC & Arg-Pro \\
13 & M adenoma (LMP) & 1 & Exon7 & aa250 & CCC-TCC & Pro-Ser \\
& & & Exon7 & aa257 & CTG-CAG & Leu-Gln \\
15 & S carcinoma & 1 & Exon5 & aa176 & TGC-TAC & Cys-Tyr \\
16 & S carcinoma & 1 & Exon4 & aa113 & TTC-TGC & Phe-Cys \\
22 & S carcinoma & 3 & Exon7 & aa245 & GGC-GAC & Gly-Asp \\
24 & S carcinoma & 3 & Exon5 & aa127 & TCC-TTC & Ser-Phe \\
26 & S carcinoma & 3 & Exon4 & aa106-aa125 & 873 bp-930bp deleted & Stop codon at aa150 \\
29 & S carcinoma & 3 & Exon7 & aa234 & TAC-CAC & Tyr-His \\
33 & M carcinoma & 3 & Exon6 & aa206 & TTG-TAG & Leu-stop \\
& & & Intron7 & Intron7.3'splice & AG-AT & Intron7 inserted \\
36 & E carcinoma & 3 & Exon5 & aa162 & ATC-AAC & Ile-ASn \\
\hline
\end{tabular}

*S, serous; M, mucinous; E, endometrioid.

**Arg to Pro change in codon 72 is described as polymorphism. 
human papilloma virus and the p53 binding protein MDM-2 ${ }^{(28-29)}$.

In summary, we have found that nine of 18 tumors with aberrant p53 or p21 expression exhibit at least one p53 mutation. These nine tumors all underexpress p21 mRNA. Four other tumors also underexpress p21, suggesting that p53 dysfunction of p21 underexpression may arise by mechanisms other than p53 mutation; for example, inactivation by endogenous or viral binding proteins or transcriptional activation by pathways independent of $\mathrm{p} 53$. The data suggest that p21 mRNA underexpression is a useful indicator of p53 dysfunction and may also reflect p53 independent pathways of p21 expression that result in loss of cell cycle control.

\section{Acknowledgments}

The authors acknowledge the participation of the following divisions of the Cooperative Human Tissue Network (CHTN) in providing tumor tissue: Western Division, Case Western Reserve University, Cleveland, $\mathrm{OH}$; Midwestern Division, Ohio State University, Columbus, OH; Eastern Division, NDRI, Philadelphia, PA; Pediatric Division, Children's Hospital, Columbus, $\mathrm{OH}$; Southern Division, University of Alabama at Birmingham, Birmingham, AL.

\section{References}

1 Boring CC, Squires TS, Tong T. Cancer Statistics 1992; 42: 1938.

2 Averette HE, Hoskins W, Nguyen HN, et al. National survey of ovarian carcinoma. Cancer 1993; 71: 1629-38.

3 Hunter T. Cooperation between oncogenes. Cell 1991; 64: 249-70.

4 Bast RC, Boyer CM, Jacobs I. et al. Cell growth retardation in epithelial ovarian cancer. Cancer 1993; 71: 1597-601.

5 Kastan MB, Onyekwere O, Sidransky D, Vogelstein B, Craid RW. Participation of p53 protein in the cellular response to DNA damage. Cancer Res 1991; 51: 6304-11.

6 Shah P, Bovey R, Tardy S, Sahli R, Sordat B, Costa J. Induction of apoptosis by wild-type p53 in a human colon tumor-derived cell line. Proc Natl Acad Sci USA 1992; 89: 4495-9.

7 Lowe SW, Schmitt EM, Smith SW, Osborne BA, Jacks T. p53 is required for radiation-induced apoptosis in mouse thymocytes. Nature 1993; 362: 847-9.

8 Xiong Y, Hannon GJ, Zhang H, Casso D, Kobayashi R, Beach D. p21 is a universal inhibitor of cyclin kinases. Nature 1993; 366: 701-4.

9 El-Deiry WS, Tokino T, Velculescu VE, et al. WAF1, a potential mediator of p53 tumor suppression. Cell 1993; 75: 817-25.

10 Harper JW, Adami GR, Wei N, Keyomarsi K, Elledge SJ. The p21 cdk-interacting protein Cip1 is a potent inhibitor of G1 cyclin-dependent kinases. Cell 1993; 75: 805-16.

11 Noda A, Ning Y, Venable SF, Pereira-Smith OM, Smith JR. Cloning of senescent cell-derived inhibitors of DNA synthesis using an expression screen. Exp Cell Res 1994; 211: 90-8.

12 Shinohara M, El-Deiry WS, Wada M, et al. Absence of WAF1 mutation in a variety of human malignancies. Blood 1994; 84: 3781-4.

13 Noonan KE, Beck C, Holzmayer TA, et al. Quantitative analysis of MDR1 (multi-drug resistance) gene expression in human tumors by polymerase chain reaction. Proc Natl Acad Sci USA 1990; 87: 7160-4.

14 Lamb P, Crawford L. Characterization of the human p53 gene. Mol Cell biol 1986; 6: 1379-85.

15 Hall JL, Dudley L, Dobner PR, Lewis SA, Cowan NJ. Identification of two human $\beta$-tubulin isotopes. Mol Cell Biol 1983; 3: 854-62.

16 Weinberg RA. The retinoblastoma protein and cell cycle control. Cell 1995; 81: 323-30.

17 Nigro JM, Baker SJ, Preisinger AC, et al. Mutations in the p53 gene occur in diverse human tumour types. Nature 1989; 342: 705-8.

18 Kupryjanczyk J, Thor AD, Beauchamp R, et al. p53 gene mutation and protein accumulation in human ovarian cancer. Proc Natl Acad Sci USA 1993; 90: 4961-5.

19 Milner BJ, Allan LA, Eccles DM, et al. p53 mutation is a common genetic event in ovarian carcinoma. Cancer Res 1993; 53: 2128-32.

20 Kohler MF, Marks JR, Wiseman RW, et al.. Spectrum of mutation and frequency of allelic deletion of the p53 gene in ovarian cancer. J Natl Cancer Inst 1993; 85: 1513-19.

21 Niwa K, Itoh M, Murase T, et al. Alteration of p53 gene in ovarian carcinoma: Clinicopathological correlation and prognostic significance. Br J Cancer 1994; 70: 1191-7.

22 McManus DT, Yap EPH, Maxwell P, Russel SEH, Toner PG, McGee J'OD. p53 expression, mutation, and allelic deletion in ovarian cancer. J Pathol 1994; 174: 159-68.

23 Teneriello MG, Ebina M, Linnoila RI, et al. p53 and K-ras gene mutations in epithelial ovarian neoplasms. Cancer Res 1993; 53: 3103-8.

24 Levine AJ, Perry ME, Chang A, et al. The role of the p53 tumor-suppressor gene in tumorigenesis. Br J Cancer 1994; 69: 409-16.

25 Rogel A, Popliker M, Webb CG, Oren M, Webb CG, Oren M. p53 cellular tumor antigen: Analysis of mRNA levels in normal adult tissues, embryos and tumors. Mol Cell Biol 1985; 5: 2851-5.

26 Finlay CA, Hinds PW, Tan TH, Eliyahu D, Oren M, Levine AJ. Activating mutations for transformation by $\mathrm{p} 53$ produce a gene product that forms a hsc70-p53 complex with an altered half-life. Mol Cell Biol 1988; 8: 531-9.

27 Werness BA, Levine AJ, Howley PM. Association of human papillomavirus types 16 and 18 E6 proteins with p53. Science 1990; 248: 76-9.

28 Chen J, Marechal, Levine AJ. Mapping of the p53 and mdm2 interaction domains. Mol Cell Biol 1993; 13: 107-14.

29 Oliner JD, Pietenpol JA, Thiagalingam S, Gyures J, Kinzler $\mathrm{KW}$, Vogelstein B. Oncoprotein MDM2 conceals the activation domain of tumor suppressor p53. Nature 1993; 632: 857-60.

Accepted for publication May 2, 1997 